University of Montana

ScholarWorks at University of Montana

6-1996

\title{
Temperature-Driven Variation in Substrate Oxygenation and the Balance of Competition and Facilitation
}

\author{
Ragan M. Callaway \\ University of Montana - Missoula, Ray.Callaway@mso.umt.edu \\ Leah King
}

Follow this and additional works at: https://scholarworks.umt.edu/biosci_pubs

Part of the Biology Commons

Let us know how access to this document benefits you.

\section{Recommended Citation}

Callaway, Ragan M. and King, Leah, "Temperature-Driven Variation in Substrate Oxygenation and the Balance of Competition and Facilitation" (1996). Biological Sciences Faculty Publications. 304.

https://scholarworks.umt.edu/biosci_pubs/304

This Article is brought to you for free and open access by the Biological Sciences at ScholarWorks at University of Montana. It has been accepted for inclusion in Biological Sciences Faculty Publications by an authorized administrator of ScholarWorks at University of Montana. For more information, please contact scholarworks@mso.umt.edu. 


\title{
TEMPERATURE-DRIVEN VARIATION IN SUBSTRATE OXYGENATION AND THE BALANCE OF COMPETITION AND FACILITATION ${ }^{1}$
}

\author{
Ragan M. Callaway and Leah King \\ Division of Biological Sciences, University of Montana, Missoula, Montana 59812 USA
}

\begin{abstract}
Emergent wetland plants often alleviate the effects of anaerobic soils on root respiration by passively transporting oxygen belowground through continuous air spaces (aerenchyma) in leaves and roots. Oxygen leaked from the roots into the rhizosphere may oxidize minerals in the soil or become available to other plants. Some spatial patterns in marsh plant communities suggest interspecific facilitative interactions, but there is little experimental evidence for interplant facilitation via soil oxygenation. We investigated the capability of the widespread, highly aerenchymous wetland plant, Typha latifolia, to aerate sediments and affect the growth of two non-aerenchymous neighbors, Salix exigua and Myosotis laxa, both in greenhouse experiments and in a natural pothole pond in western Montana. At soil temperatures of $11^{\circ}-12^{\circ} \mathrm{C}$ in the greenhouse, mean dissolved oxygen (DO) ranged from $2.75 \pm 0.41$ to $4.43 \pm 1.11 \mathrm{mg} / \mathrm{L}$ (mean $\pm 1 \mathrm{SE}$ ) in pots with Typha, whereas in pots without Typha DO content ranged from $0.40 \pm 0.06$ to $0.65 \pm 0.06 \mathrm{mg} / \mathrm{L}$. At soil temperatures of $18^{\circ}-20^{\circ} \mathrm{C}, \mathrm{DO}$ in the Typha treatment was lower than in the low-temperature experiment and did not differ significantly from DO in the pots without Typha. At substrate temperatures of $11^{\circ}-12^{\circ} \mathrm{C}$, all rooted Salix cuttings survived when planted with Typha, whereas none survived when planted alone. At the same substrate temperature, Myosotis transplants grew significantly larger when planted with Typha than when alone, also indicating that facilitation occurred. When grown with Typha at soil temperatures of $18^{\circ}-$ $20^{\circ} \mathrm{C}$, however, Myosotis root mass was significantly less than when grown alone, suggesting that competition occurred. At the pond margins where Typha and Myosotis coexist in watersaturated soils, naturally occurring Myosotis plants adjacent to transplanted Typha had significantly larger shoot and fruit mass than did control Myosotis without nearby Typha. In this experiment DO levels in soil water and available soil nitrogen did not differ among treatments. These experiments indicate that aerenchymous wetland plants have the potential to facilitate neighbors via soil oxygenation, and that facilitation and competition may shift in importance with changes in the physical environment.
\end{abstract}

Key words: aerenchyma; cattails; competition; facilitation; interference; nitrogen; oxygen; roots; soil temperature; Typha; Montana; wetlands.

\section{INTRODUCTION}

Interference among emergent freshwater plants has been well documented with experimental manipulations in natural environments (Grace and Wetzel 1981, Grace 1987, 1988, Gopal and Goel 1993). Light and nitrogen have been identified as primary limiting resources, but substrate oxygen may also limit plant growth in wetlands (Drew 1983). To alleviate oxygen limitation in their roots, many wetland emergent plants passively transport oxygen from leaves to roots through aerenchymous tissue (Armstrong 1964, 1979). In some cases oxygen may leak out of submerged roots and oxidize toxic substances and nutrients in the rhizosphere and oxygenate marsh sediments (Green and Etherington 1977, Carlson and Forrest 1982, Howes et al. 1981, Dunbabin et al. 1988, Armstrong et al. 1992) although the extent and importance of rhizosphere oxidation is controversial (Morris and Dacey 1984, Brix 1988, Bedford et al. 1991). Schat and Van Beckhoven

${ }^{1}$ Manuscript received 12 December 1995; revised 3 July 1995; accepted 21 August 1995.
(1991) reported that Plantago coronopus and Samolus valerandi were tightly clumped around tussocks of the aerenchymous Juncus maritimus in dune slacks on the coast of Holland, where survival rates appeared to be enhanced by soil oxygenation and oxidation of iron, manganese, and sulfide. These, and similar spatial patterns in saltmarshes (Castellanos et al. 1994, Bertness and Yeh 1994), and bogs (Berendse and Aerts 1984), and field experiments conducted by Hacker and Bertness (1995) in saltmarshes suggest that positive interactions involving transported oxygen may occur between highly aerenchymous and less-aerenchymous plants.

We studied facilitation and rhizosphere oxidation in a "pothole" pond in the Swan Valley of western Montana. These glacially derived ponds support a diverse array of emergent macrophytes, including the highly aerenchymous Typha latifolia L. (cattail). Typha latifolia occurs in dense, virtually monospecific stands in deep water, and in diverse stands in shallow water at the pond margins, which include species that are much less aerenchymous. Although facilitation has been studied experimentally in many natural systems and 
operates via many mechanisms (Attsat and O'Dowd 1976, Hunter and Aarssen 1990, Callaway 1992, 1994, 1995, Bertness and Shumway 1993, Bertness and Callaway 1994), facilitation via soil aeration has never been experimentally studied in natural freshwater systems. Here we focus on the following questions: (1) Does Typha oxygenate sediments in which it grows? (2) Does Typha facilitate less aerenchymous neighbors? and (3) Do facilitative effects change with variation in the physical environment? We pursued answers to these questions by conducting experiments both in the field and in the greenhouse.

\section{STUDY AREA}

We conducted field experiments and collected plants for greenhouse experiments from a single pond in the Swan Valley, Montana $\left(47^{\circ} 44^{\prime} \mathrm{N}, 113^{\circ} 48^{\prime} \mathrm{W}, 950 \mathrm{~m}\right.$ elevation). Typha latifolia is widely distributed throughout North America and has exceptionally aerenchymous shoots and roots. The effects of Typha were tested on Salix exigua Nutt. (narrow-leaved willow) and Myosotis laxa Lehm. (small-flowered forget-menot). Salix exigua is commonly found at the upper edges of wetlands and riparian zones in western Montana and has completely woody, nonaerenchymous stems. Myosotis stems have a small central air chamber, but the leaves are not aerenchymous. Myosotis typically is found intermixed with Typha lower on the pond margins, and $S$. exigua often grows at the upper edge of the Typha-dominated vegetation.

\section{METHODS}

In September, 1993, mature Typha individuals were transplanted from the pond into 2.25 -L undrained plastic pots. Soil in the pots consisted of $80 \%$ natural pond soil and $20 \%$ peat. The soil mixture was also placed in 2.25-L undrained pots without cattails. Distilled water was added as required to maintain a depth of 1-2 $\mathrm{cm}$ above the soil surface. Algae were controlled with copper sulfate added in equal amounts to all pots in both treatments. Experiments were conducted at two different soil temperatures. The pots were kept in wading pools through which tap water continually flowed in order to maintain cool soil temperatures (range during experiment was $11^{\circ}-12^{\circ} \mathrm{C}$ ). Water from the wading pools was not allowed to flow into the pots. For the high soil temperature experiment, flow was cut off and standing water was left in the pools to buffer daily fluctuations in temperature (which ranged from $18^{\circ}$ to $20^{\circ} \mathrm{C}$ during the experiment) in the 2.5 - L pots. A 70 $\mathrm{d}$ establishment and acclimation period and the experiments were conducted under a combination of natural and supplemental high-pressure sodium light (photon flux density $\approx 500 \mu \mathrm{mol} \cdot \mathrm{m}^{-2} \cdot \mathrm{s}^{-1}$ ) set for a $12: 12$ light: dark photocycle. Midday air temperature in the greenhouse ranged from $18^{\circ}$ to $22^{\circ} \mathrm{C}$ in both high and low substrate temperature experiments.

Dissolved oxygen (DO) was measured between 0800 and 1000 on all days, with a Cole-Parmer Model 551355 meter. The probes cannot be pushed directly into soil so DO was measured in water that percolated into perforated plastic tubes pushed into the waterlogged soil and left at permanent locations in the pots. Tubes were located midway between the Typha shoot and the edge of the pot and DO was measured at a depth of 12 $\mathrm{cm}$. Calibrations were performed at the temperatures of the experiment. DO was measured while the probe was gently agitated and after the readout had stabilized. A single Typha root-rhizome mass was transplanted to each of 16 randomly selected pots, and 8 control pots were established without Typha. Following the 70-d establishment period, during which new leaves developed, DO was measured on four different days over a 9 -d period. Afterwards, the flow of water through the pools was stopped and the pots were allowed to warm. Beginning $4 \mathrm{~d}$ later, DO was measured four times during a 7-d period.

After the completion of the preceding experiment, flow was resumed in the pools to cool the pots back to $11^{\circ}-12^{\circ} \mathrm{C}$ and Salix exigua clones, prepared from cuttings of a single shrub, were planted in the treatment and control pots. These clones were also collected in September, 1993, and grown together in moist but not saturated soil during the 70-d establishment period. All clones were between 10 and $15 \mathrm{~cm}$ in height and produced substantial root systems during the establishment period. Salix clones were grown and checked for mortality over a $17-d$ period. A Salix clone was presumed dead when all leaves were either yellow or brown.

All Salix clones then were removed, and similarsized Myosotis laxa rosettes that also had been collected in September were transplanted into the treatment and control pots. After $40 \mathrm{~d}$ at soil temperatures of $11^{\circ}-12^{\circ} \mathrm{C}$, Myosotis were harvested, and maximum root length was measured. Plants were divided into roots and shoots, then dried at $60^{\circ} \mathrm{C}$ for $5 \mathrm{~d}$ and weighed. Flow of the coolant water was then stopped, warming the pots to $18^{\circ}-20^{\circ} \mathrm{C}$, and a second cohort of Myosotis were planted. After $40 \mathrm{~d}$ these plants were harvested and measured as in the low-temperature experiment. At the times of all transplantings, soil in the control pots was similarly disturbed to control for changes due to the transplanting process. Control and treatment pots were randomly located under the lights and rotated so that Salix and Myosotis in both treatments experienced similar shade conditions.

To test the effects of rhizosphere oxidation and facilitation in the field, Typha transplant experiments were conducted in the summer of 1994 at the same pond in the Swan Valley from which the greenhouse plants had been collected. In June, root-rhizome balls and shoots of 20 mature Typha were excavated, and each was relocated $10 \mathrm{~cm}$ from a Myosotis rosette along the margin of the pond where soils were saturated but not continuously submerged throughout the summer. Twenty additional Myosotis rosettes that were at least 


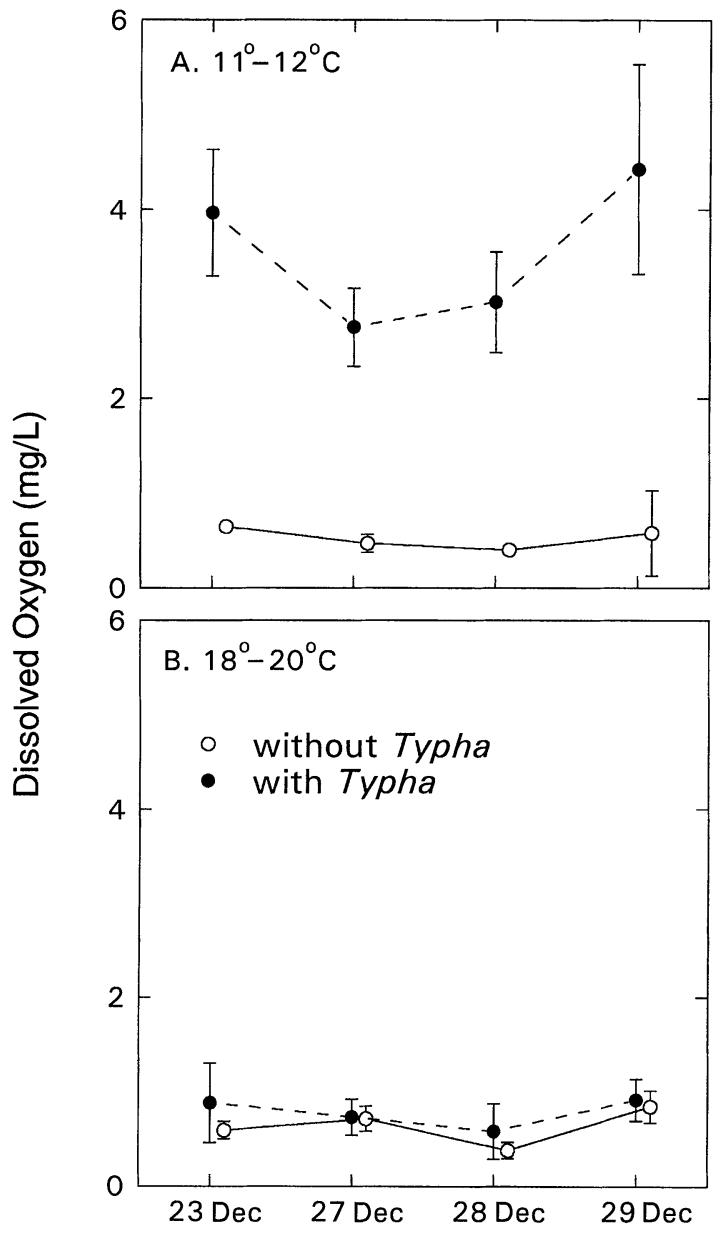

FIG. 1. Dissolved oxygen in soil water in pots with and without Typha latifolia when plants were grown at different substrate temperatures in greenhouse conditions. Data are means \pm 2 SE. All daily comparisons showed significant differences between treatments (Student's $t$ tests, $n_{\text {control }}=8$ measurements, $n_{\text {treatment }}=16, P<0.01$ ).

$1 \mathrm{~m}$ away from the nearest Typha were marked and used for controls. All 40 Myosotis rosettes were initially between 5 and $8 \mathrm{~cm}$ in diameter.

Soil near control rosettes was excavated and refilled to simulate physical disturbance associated with transplanting. Dissolved oxygen was measured four times during the summer in perforated PVC (polyvinyl chloride plastic) tubes inserted into the soil next to each of the 40 experimental Myosotis plants. In late July, plant height was recorded and shoots of the 40 treatment and control Myosotis plants were harvested, divided into roots, shoots, and fruits, dried at $60^{\circ} \mathrm{C}$ for $5 \mathrm{~d}$, and weighed. A single soil sample was collected at $7 \mathrm{~cm}$ in depth at the edge of each rosette. Available soil nitrogen (ammonium plus nitrate) were analyzed following Setaro and Jones (1989).

\section{RESULTS}

Over a 9-d period during which soil temperature was between $11^{\circ}$ and $12^{\circ} \mathrm{C}$, soil water in pots containing
Typha consistently had higher dissolved-oxygen (DO) content than in pots without Typha (Fig. 1). Mean soil DO values in pots with Typha ranged from $2.75 \pm 0.41$ to $4.43 \pm 1.11 \mathrm{mg} / \mathrm{L}$ (mean $\pm 1 \mathrm{SE}$ ); these were significantly higher than means in pots without Typha, which ranged from $0.40 \pm 0.06$ to $0.65 \pm 0.06 \mathrm{mg} / \mathrm{L}$. In experiments conducted at soil temperatures of $18^{\circ}-20^{\circ} \mathrm{C}$, however, DO decreased to an overall mean of $0.78 \mathrm{mg} /$ $\mathrm{L}$ in pots with Typha, which did not differ significantly on any days from DO in pots without Typha (Fig. 2).

All Salix cuttings planted with Typha survived for the 17-d duration of the experiment (Fig. 3). However, when planted without Typha, 50\% were dead within 7 $\mathrm{d}$ and all died by the 11 th day of the experiment. Experiments with Salix were conducted only at $11^{\circ}-12^{\circ} \mathrm{C}$.

At cool soil temperatures $\left(11^{\circ}-12^{\circ} \mathrm{C}\right)$, no Myosotis died during the 40-d experiment whether or not they were planted with Typha. However, final root and shoot masses of Myosotis that shared pots with Typha were two and three times larger, respectively, than those grown without Typha (Fig. 4A). Likewise, mean root length of Myosotis grown with Typha was significantly greater. Although comparisons were confounded by different experimental periods, DO in soil water was substantially lower in pots with Typha during the coplanting experiments (mean DO ranged from $1.72 \pm$ 0.88 to $2.24 \pm 0.58 \mathrm{mg} / \mathrm{L}$ on three different days) than when Typha was grown alone (Fig. 1), suggesting that Salix and Myosotis roots may have decreased dissolved oxygen in the pots.

In the experiment conducted at high soil temperatures $\left(18^{\circ}-20^{\circ} \mathrm{C}\right)$, Myosotis planted with Typha were generally smaller than when grown alone (Fig. 4B). Root mass of Myosotis in the control was significantly lower with Typha (Student's $t=2.163, P=0.042$ )

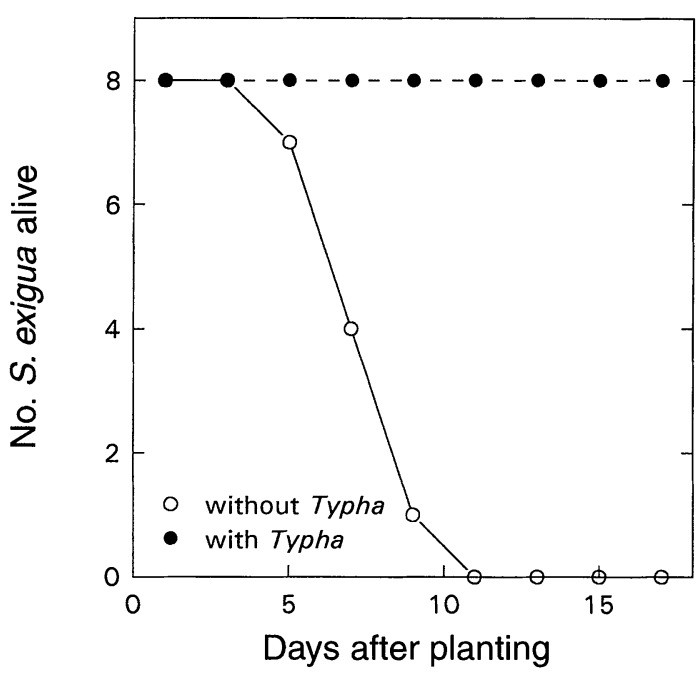

FIG. 2. Survival of cloned cuttings of Salix exigua when grown with and without Typha latifolia at substrate temperatures of $11^{\circ}-12^{\circ} \mathrm{C}$ under greenhouse conditions. $n_{\text {control }}=8$ cuttings, $n_{\text {treatment }}=8$ cuttings. 


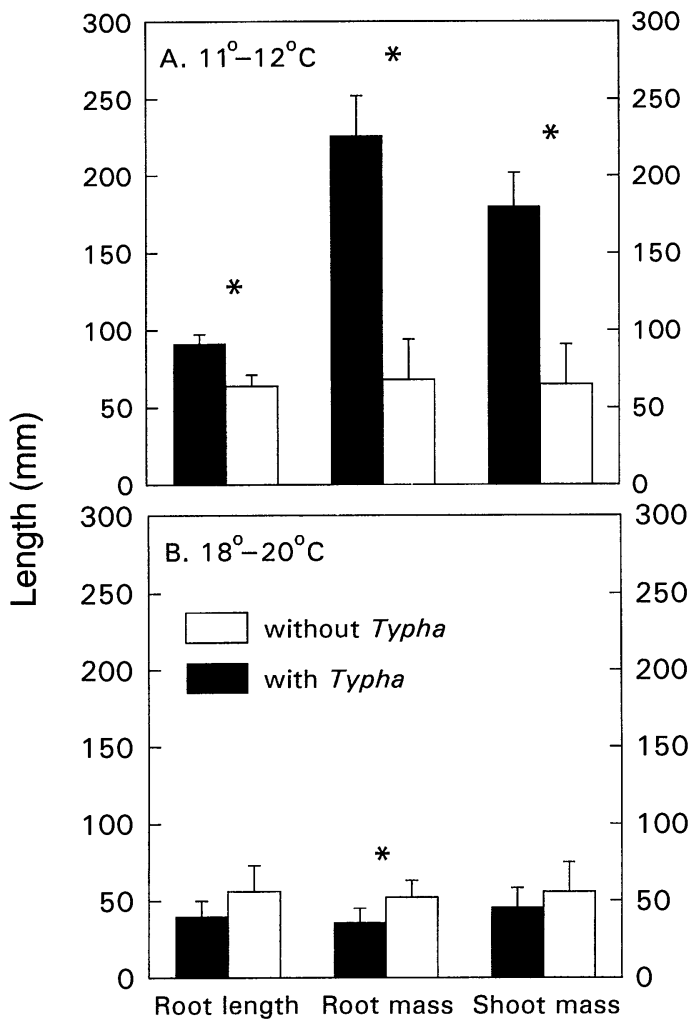

FIG. 3. Growth characteristics of Myosotis laxa when grown for $40 \mathrm{~d}$ with and without Typha latifolia under greenhouse conditions at two different substrate temperatures. Narrow bars represent $\pm 2 \mathrm{SE}$, and an $*$ designates a significant difference between treatments at $P<0.01$ (Student's $t$ test, $n_{\text {control }}=8$ rosettes, $n_{\text {treatment }}=16$ rosettes.

than when alone, but shoot length $(t=1.748, P=0.094)$ and shoot mass $(t=0.890, P=0.383)$ did not differ significantly between treatments.

During the field experiment at the Swan Valley pond, the mean temperatures of the soil water ranged from $11.4^{\circ}$ to $13.2^{\circ} \mathrm{C}$. Soil solution DO and available soil nitrogen did not differ significantly between treatment and control in the field experiment (Fig. 4, Table 1); however, mean shoot mass and root mass of Myosotis rosettes were significantly greater when growing next to transplanted Typha than when growing alone (Table

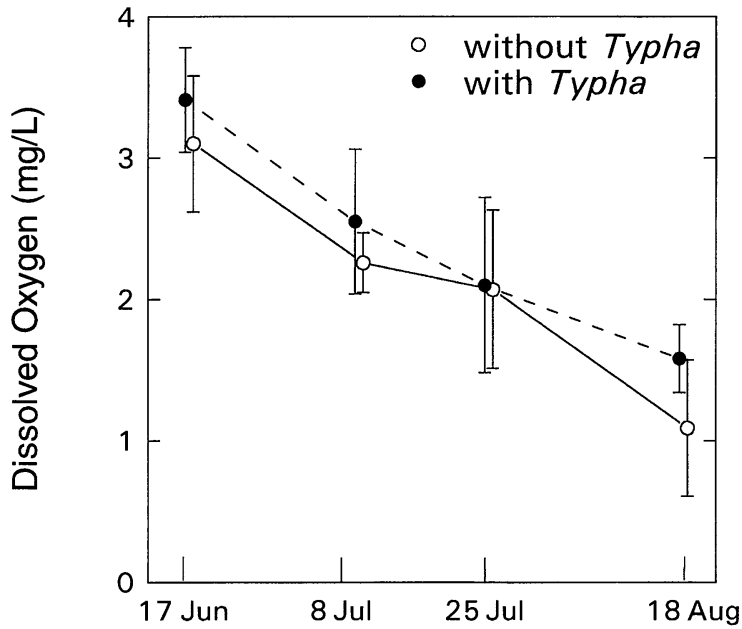

FIG. 4. Dissolved oxygen in soils in a pothole pond in the Swan Valley, Montana. Measurements were made in situ near Myosotis plants either growing adjacent to Typha latifolia or $\geq 1 \mathrm{~m}$ away from the nearest Typha plant. Data are means \pm 2 SE. No daily comparison showed a significant difference (Student's $t$ tests, $n_{\text {control }}=20$ measurements, $n_{\text {treatment }}$ $=20, P>0.05)$.

1). Plant height did not differ significantly between treatments, but Myosotis growing next to Typha produced more than twice as much fruit mass as those growing alone.

\section{DISCUSSION}

Greenhouse and field experiments indicated that the highly aerenchymous Typha can aerate soil near its roots and improve the growth and reproductive capacity of less aerenchymous neighbors under some conditions. Our greenhouse experiments also indicate that the interaction between Typha and its neighbors may be highly asymmetrical (see Connell 1983) and shift between facilitation and competition as the physical environment (substrate temperature) varies. We have not, however, provided a conclusive connection between rhizosphere oxygenation and either the positive or negative effects of Typha on the survival, growth, and reproduction of its neighbors.

Previous studies of oxygen transport through leaves

TABLE 1. Characteristics of Myosotis laxa individuals grown either next to planted Typha latifolia, or $\geq 1 \mathrm{~m}$ from the closest T. latifolia, in field experiments in Montana. Values shown are means \pm 1 SE. $n=20$ plants.

\begin{tabular}{|c|c|c|c|c|}
\hline & \multicolumn{2}{|c|}{ Treatment } & \multirow[b]{2}{*}{$t$} & \multirow[b]{2}{*}{$P$} \\
\hline & With $T$. latifolia & Without $T$. latifolia & & \\
\hline \multicolumn{5}{|l|}{ Myosotis characteristics } \\
\hline Shoot mass (mg) & $93.6 \pm 11.1$ & $66.5 \pm 7.9$ & 2.07 & 0.045 \\
\hline Shoot height (mm) & $72.4 \pm 3.9$ & $64.9 \pm 5.2$ & 1.16 & 0.255 \\
\hline Root mass (mg) & $49.1 \pm 4.1$ & $34.1 \pm 3.9$ & 2.63 & 0.012 \\
\hline Fruit mass (mg) & $0.56 \pm 0.06$ & $0.20 \pm 0.03$ & 5.15 & $<0.001$ \\
\hline \multicolumn{5}{|l|}{ Soil characteristics } \\
\hline Nitrate \pm ammonium ( $\mu \mathrm{g} / \mathrm{g}$ soil $)$ & $3.82 \pm 0.37$ & $3.16 \pm 0.45$ & 1.12 & 0.271 \\
\hline
\end{tabular}


and roots into the rhizosphere have produced conflicting results. Some aerenchymous emergent wetland plants transport enough oxygen belowground to sustain aerobic root respiration and to oxidize compounds near root surfaces, as demonstrated by the reddish streaks of oxidized iron that often develop on or near roots in anaerobic sediments (Green and Etherington 1977, Gambrell and Patrick 1978, Armstrong 1979). Emergent or submerged aquatic plants may increase sediment redox potentials or oxygen concentrations in some cases (Wium-Anderson and Anderson 1972, Howes et al. 1981, Sand-Jensen et al. 1982, Sand-Jensen and Prahl 1982, Jaynes and Carpenter 1986, Armstrong et al. 1992). Conversely, others have measured substantial oxygen transport from shoots to roots, but little net change of $\mathrm{O}_{2}$ concentration in the rhizosphere (Morris and Dacey 1984, Brix 1988, Bedford et al. 1991). This controversy is featured in a current exchange between Sorrell and Armstrong (1994) and Bedford and Bouldin (1994).

Respiration rates vary greatly with temperature, therefore differences in the temperatures at which oxygen efflux was measured may explain the differences we found for the effect of Typha on substrate dissolved oxygen (DO) at high and low temperature, and may account for some of the discrepancies among previous studies (see Gries et al. 1990). In our experiment, there were no significant differences between DO in Typha and no-Typha controls when pots were maintained at $18^{\circ}-20^{\circ} \mathrm{C}$. However, when pots were maintained at $11^{\circ}-$ $12^{\circ} \mathrm{C}$, differences in DO in soil water were substantial. It is possible that increased root respiration by roots or soil microbes at higher temperatures mitigated net oxygenation, but respiration was not measured in this study. Howes and Teal (1994) found that net oxygen loss from Spartina alterniflora roots did not occur at ambient chamber temperatures of $25^{\circ} \mathrm{C}$ and $9^{\circ} \mathrm{C}$, but did occur at $6^{\circ} \mathrm{C}$.

There are a number of other possible reasons for contradictory results reported in the literature on rhizosphere oxygenation by aerenchymous plants. Differences may arise from the use of different techniques to measure rhizosphere oxygenation. In some studies redox potential was used to infer oxygenation. However, redox potential is influenced by many factors, and provides only a qualitative measure of dissolved oxygen in sediment pore water. Other inconsistencies may occur because some estimates of oxygen efflux were made using excised plant parts and others were based on whole-plant gas balance (see Bedford et al. 1991). Another potential (and seldom reported) cause of conflicting results in sediment oxidation studies may be due to differences in biomass allocation of the plants being tested. The rate of oxygen transport to roots and the rhizosphere is partially dependent on shoot: root ratios as large leaf areas may provide a greater surface area for photosynthetic generation or stomatal conductance of oxygen than small leaf areas. For all treatments combined in our greenhouse study, shoot: root mass ratios of Typha were $0.88 \pm 0.23$ in the cool-temperature experiment and $0.91 \pm 0.24$ in the warm-temperature experiment, and not significantly different. We did, however, find that shoot:root mass ratio of Typha was positively correlated with soil DO content $(r=0.77)$ in the cool-temperature experiment with Typha alone.

Intense competition has been measured between emergent wetland species that are highly aerenchymous (Grace 1987, 1988, Gopal and Goel 1993). However, in these cases effects were tested between highly aerenchymous species, and thus these species would be less likely to compete for soil oxygen. In other studies, highly aerenchymous plants with superior abilities to transport oxygen appeared to facilitate less-aerenchymous species. Castellanos et al. (1994) reported that Spartina maritima aerates surface sediments in southern Spain, creating conditions favorable for the invasion of Arthrocnemum perenne. In eastern saltmarshes in North America, Hacker and Bertness (1995) found that the aerenchymous Juncus maritimus increased the redox potential in its rhizosphere, which corresponded with increased growth of Iva frutescens, a woodystemmed perennial. Spatial associations of Plantago coronopus and Samolus valerandi with tussocks of the aerenchymous Juncus maritimus in northern Europe were attributed to soil oxygenation (Schat 1984, Schat and Van Beckhoven 1991).

Neither Salix nor Myosotis is highly aerenchymous; thus the positive effects of soil oxygenation on these species, which are unlikely to oxygenate their own roots effectively, may have been more important than any concurrent competition for nutrients or light. Such complex combinations of competitive and facilitative mechanisms have been described in oak woodlands (Callaway et al. 1991), coastal salt marshes (Bertness and Shumway 1993, Bertness and Hacker 1994, Bertness and Yeh 1994, Callaway 1994), and intertidal seaweed communities (Hay 1986). In the greenhouse, interactions between Typha and Myosotis shifted between facilitation and competition depending on the temperature of the substrate. At cool temperatures, DO in pots increased with Typha and Myosotis were larger when grown with Typha. At warm sediment temperatures, oxygen was not higher in pots with Typha than in controls, and Myosotis root mass was smaller when plants were grown with Typha. This suggests that the interactions between aerenchymous plants and their neighbors may fluctuate in nature with changes in the physical environment. However, these interpretations of the differences between the high- and low-temperature experiments should be viewed with caution because they were not conducted concurrently. Factors that may have differed between the two experiments include depletion of nutrients in the substrate, differences in Typha or Myosotis lifestages, and different oxygen solubility.

In our field experiment, the net seasonal effect of Typha on Myosotis was positive; Myosotis attained 
greater shoot, root, and fruit mass. Even though soil temperatures in the field were comparable to those in the low-temperature, greenhouse experiment, we found no net increase of DO in the Typha treatments. This may have been a result of many factors: oxygen may have been taken up by the nonaerenchymous plants near the Typha, more oxygen may have been consumed via respiration by plant roots or soil microorganisms, or sediments in the field may have been more reducing than those used in the greenhouse. On the other hand, these results may indicate that substantial sediment oxygenation did not occur in the field and positive effects were due to other factors such as shade.

Considered together, our experiments indicated that oxygen release from roots can be an important factor in interactions among freshwater marsh plants. The apparently transient nature of this mechanism and the potential for environmental variation to shift effects from facilitation to competition add to the expanding body of literature that suggests that our understanding of species interactions cannot be based strictly on competition for limiting resources, and that complex combinations of mechanisms must be explored to fully understand species interactions in nature.

\section{Literature Cited}

Armstrong, J., W. Armstrong, and P. M. Becket. 1992. Phragmites australis: Venturi- and humidity-induced pressure flows enhance rhizome aeration and rhizosphere oxidation. New Phytologist 120:197-207.

Armstrong, W. 1964. Oxygen diffusion from the roots of some British bog plants. Nature 204:801-802.

- 1979. Aeration in higher plants. Advances in Botanical Research 7:226-332.

Attsat, P. R., and D. J. O'Dowd. 1976. Plant defense guilds. Science 193:24-29.

$\rightarrow$ Bedford, B. L., and D. R. Bouldin. 1994. Response to the paper "On the difficulties of measuring oxygen release by root systems of wetland plants," by B.K. Sorrell and W. Armstrong. Journal of Ecology 82:185-186.

Bedford, B. L., D. R. Bouldin, and B. D. Beliveau. 1991. Net oxygen and carbon-dioxide balances in solutions bathing roots of wetland plants. Journal of Ecology 79:943959.

Berendse, F., and R. Aerts. 1984. Competition between Erica tetralix L. and Molinia caerulea (L.) Moench as affected by the availability of nutrients. Acta Oecologia Plantarum 5:3-14.

Bertness, M. D., and R. M. Callaway. 1994. Positive interactions in communities. Trends in communities. Trends in Ecology and Evolution 9:191-193.

Bertness, M. D., and S. Hacker. 1994. Physical stress and positive associations among marsh plants. American Naturalist 144:363-372.

Bertness, M. D., and S. Shumway. 1993. Competition and facilitation in marsh plants. American Naturalist 142:718724.

Bertness, M. D., and S. M. Yeh. 1994. Cooperative and competitive interactions in the recruitment of marsh elders. Ecology 75:2416-2429.

Brix, H. 1988. Light-dependent variations in the composition of the internal atmosphere of Phragmites australis (Cav.) Trin. ex Steudel. Aquatic Botany 30:319-329.

Callaway, R. M. 1992. Effect of shrubs on the recruitment of Quercus douglasii and Quercus lobata in California. Ecology 73:2118-2128.

1994. Facilitating and interfering effects of Arthrocnemum subterminale on winter annuals in a California salt marsh. Ecology 75:681-686.

. 1995. Positive interactions among plants. Botanical Review 61:306-349.

Callaway, R. M., N. M. Nadkarni, and B. E. Mahall. 1991. Facilitation and interference of Quercus douglasii on understory productivity in central California. Ecology 72: 1484-1499.

Carlson, P. R., and J. Forrest. 1982. Uptake of dissolved sulfide by Spartina alterniflora: evidence from natural sulfur isotope abundance ratios. Science 216:633-635.

Castellanos, E. M., M. E. Figueroa, and A. J. Davy. 1994. Nucleation and facilitation in saltmarsh succession: interactions between Spartina maritima and Arthrocnemum perenne. Journal of Ecology 82:239-248.

Connell, J. H. 1983. On the prevalence and relative importance of interspecific competition: evidence from field experiments. American Naturalist 122:661-696.

Drew, M. C. 1983. Plant injury and adaptation to oxygen deficiency in the root environment. Plant and Soil 75:179199.

Dunbabin, J. S., J. Porkony, and K. H. Bowmer. 1988. Rhizosphere oxidation by Typha domingensis Pers. in miniature artificial wetland filters used for metal removal from waste waters. Aquatic Botany 29:303-317.

Gambrell, R. P., and W. H. Patrick, Jr. 1978. Chemical and microbiological properties of anaerobic soils and sediments. Pages 375-423 in D. D. Hook and R. M. M. Crawford, editors. Plant life in anaerobic environments. Ann Arbor Science, Ann Arbor, Michigan, USA.

Gopal, B., and U. Goel. 1993. Competition and allelopathy in aquatic plant communities. Botanical Review 59:155210.

Grace, J. B. 1987. The impact of pre-emption on the zonation of Typha species along lakeshores. Ecological Monographs 57:283-303.

1988. The effect of nutrient additions on mixtures of Typha latifolia and Typha domingensis. Aquatic Botany 31:83-92.

Grace, J. B., and R. G. Wetzel. 1981. Habitat partitioning and competitive displacement in cattails. American Naturalist 118:463-474.

Green, M. S., and J. R. Etherington. 1977. Oxidation of ferrous iron by rice (Oryza sativa L.) roots: a mechanism for waterlogging tolerance? Journal of Experimental Botany 28:678-690.

Gries, C., L. Kappen, and R. Lösch. 1990. Mechanism of flood tolerance in reed, Phragmites australis (Cav.) Trin. ex Steudel. New Phytologist 114:589-593.

Hacker, S. D., and M. D. Bertness. 1995. Morphological and physiological consequences of a positive plant interaction. Ecology 76:2165-2175.

Hay, M. E. 1986. Associational plant defenses and the maintenance of species diversity: turning competitors into accomplices. American Naturalist 128:617-641.

Howes, B. L., and J. M. Teal. 1994. Oxygen loss from Spartina alterniflora and its relationship to salt marsh oxygen balance. Oecologia 97:431-438.

Howes, B. L., R. W. Howarth, J. M. Teal, and I. Valiela. 1981. Oxidation-reduction potentials in a salt marsh: spatial patterns and interactions with primary production. Limnology and Oceanography 26:350-360.

Hunter, A. F., and L. W. Aarssen. 1990. Plants helping plants. Bioscience 38:34-40.

Jaynes, M. L., and S. R. Carpenter. 1986. Effects of vascular and nonvascular macrophytes on sediment redox and solute dynamics. Ecology 67:875-898. 
Morris, J. T., and J. W. H. Dacey. 1984. Effects of oxygen on ammonium uptake and root respiration by Spartina alterniflora. American Journal of Botany 71:979-985.

Sand-Jensen, K., and C. Prahl. 1982. Oxygen exchange with the lacunae and across leaves and roots of the submerged vascular macrophyte Lobelia dortmanna L. New Phytologist 91:103-120.

$\rightarrow$ Sand-Jensen, K., C. Prahl, and H. Stockholm. 1982. Oxygen release from roots of submerged aquatic macrophytes. Oikos 38:349-354.

$\rightarrow$ Schat, H. 1984. A comparative ecophysiological study on the effects of waterlogging and submergence on dune slack plants: growth survival and mineral nutrition in sand culture experiments. Oecologia 62:279-286.

Schat, H., and K. Van Beckhoven. 1991. Water as a stress factor in the coastal dune system. Pages 76-89 in J. Rozema and J. A. C. Verkleij, editors. Ecological responses to environmental stresses. Kluwer Academic, Dordrecht, The Netherlands.

Setaro, F., and J. A. Jones. 1989. Methods of nutrient analyses for ecological studies. Department of Geography Handbook, University of California, Santa Barbara, California, USA.

Sorrell, B. K., and W. Armstrong. 1994. On the difficulties of measuring oxygen release by root systems of wetland plants. Journal of Ecology 82:177-183.

Wium-Anderson, S., and J. M. Anderson. 1972. The influence of vegetation on the redox profile of the sediment of Grane Langs $\varnothing$, a Danish Lobelia lake. Limnology and Oceanography 17:948-952. 